Note

\title{
The First Case of Legionella nagasakiensis Isolation from Hot Spring Water
}

\section{KATSUNORI FURUHATA ${ }^{1 *}$, AKIKO EDAGAWA ${ }^{2,3}$, HIROSHI MIYAMOTO ${ }^{3}$, KEIICHI GOTO ${ }^{4}$, SHIN-ICHI YOSHIDA ${ }^{5}$, AND MASAFUMI FUKUYAMA ${ }^{1}$}

\author{
'School of Life and Environmental Science, Azabu University, \\ Sagamihara, Kanagawa 252-5201, Japan \\ ${ }^{2}$ Department of Environment Health, Osaka Prefectural Institute of \\ Public Health, Osaka, Osaka 537-0025, Japan \\ ${ }^{3}$ Faculty of Medicine, Saga University, Saga, Saga 849-8501, Japan \\ ${ }^{4}$ Food Research Laboratories, Mitsui Norin Co., Ltd., Fuzieda, Shizuoka 426-0133, Japan \\ ${ }^{5}$ Graduate school of Medicine Sciences, Kyushu University, Fukuoka, Fukuoka 812-8582, Japan
}

Received 16 May, 2011/Accepted 14 June, 2011

\begin{abstract}
In August, 2010, strain HYMO-6 was isolated from a sample of hot spring water in Aomori, Japan. The $16 \mathrm{~S}$ rDNA sequences $(1,496 \mathrm{bp})$ of this strain (accession number: AB597175) had a similarity of less than $96.6 \%$ to other Legionella species, prompting us to hypothesize that this strain might be a novel species belonging to the genus Legionella. However, in March of 2011, it was became clear that the HYMO-6 strain (=JCM $17450=$ KCTC $23560=$ DSM 24727) was Legionella nagasakiensis CDC-1796-JAP-E ${ }^{\top}$ (=ATCC BAA-1557 ${ }^{\top}=\mathrm{JCM} 15315^{\top}$ ). When this strain was cultured on BCYE $\alpha$ agar at $36^{\circ} \mathrm{C}$ for $7 \mathrm{~d}$, no long cells were observed. The dominant fatty acids of strain HYMO-6 were $16: 1 \omega 7 \mathrm{c}(32.4 \%)$, and the DNA G+C content was $42.0 \mathrm{~mol} \%$.
\end{abstract}

Key words : Legionella nagasakiensis / Hot spring waters/Characteristics.

The genus Legionella comprises a group of pathogenic bacteria that infect the respiratory system (Fraser et al., 1977), and about 50 species belonging to this group have been reported (Building Management Education Center, 2009). In 2002, a mass outbreak of legionellosis transmitted through hot spring water in Miyazaki Prefecture, Japan, highlighted the importance of the hygienic management of bath water (Yabuuchi and Agata, 2004). Among the causative agents of legionellosis, a respiratory disease, Legionella pneumophila is well known, and extensive information is available on this bacterium (Edelstein and Meyer, 1980; Riffard et al., 1998; Albers et al., 2005; Amemura-Maekawa et al., 2008).

We have been investigating the distribution of Legionella spp. in the water of all of the hot springs in Japan for several years (Furuhata et al, 2004;

${ }^{*}$ Corresponding author. Tel: $+81-42-754-7111$, Fax : +81 42-754-6215, E-mail:furuhata (a)azabu-u.ac.jp
Furuhata et al, 2009; Furuhata et al, 2010). Because the HYMO-6 strain that was isolated from Aomori, Japan, did not correspond to existing species of Legionella spp. when strains from hot spring water were identified by gene analysis, we thought that it was a novel species, and thus tried to examine its taxonomy. However, it recently became clear that the HYMO-6 strain isolated by our group was the same as the Legionella nagasakiensis registered by Yang et al. (2011). In this report, we describe the phenotypic and phylogenetic characteristics of the HYMO-6 strain that was isolated from hot spring water for the first time.

Strain HYMO-6 was isolated from hot spring water (quality: $41^{\circ} \mathrm{C}$, salt, $\mathrm{pH}$ 7.2) from Aomori Prefecture, Japan, in August of 2010, by a plating method using GVPC $\alpha$ medium (Nikken Bio Medical Laboratory Inc., Kyoto, Japan) at $36^{\circ} \mathrm{C}$ for $7 \mathrm{~d}$. Two hundred milliliters of hot spring water were concentrated to $1 \mathrm{ml}$ by centrifugation at $6,000 \mathrm{rpm}$ for $30 \mathrm{~min}$. This 
concentrate was mixed with an equal volume of $0.2 \mathrm{M}$ $\mathrm{HCl}-\mathrm{KCl}$ solution $(\mathrm{pH} 2.2)$, and the mixture was incubated at room temperature for 15 min. Subsequently, several colonies of each isolate suggestive of the genus Legionella were picked up, smeared onto a 2compartment agar plate (Nikken Bio Medical Laboratory Inc., Kyoto, Japan) consisting of BCYE $\alpha$ and blood agar media, and subjected to pure culture and testing for cysteine requirements. The strains that failed to grow on blood agar medium but grew on BCYE $\alpha$ medium alone were presumed to belong to the genus Legionella. The isolated strain was preserved in $20 \%(\mathrm{w} / \mathrm{V})$ skim milk, and stored at $-80^{\circ} \mathrm{C}$.

The almost complete sequence of the $16 \mathrm{~S}$ rRNA gene was determined using a MicroSeq 16S rRNA gene bacterial identification kit (Applied Biosystems). A multiple sequence alignment analysis was performed using the CLUSTAL W software program (Thompson et al., 1994) and gaps and unidentified base positions were deleted using the BioEdit (Hall, 1999) software package. Evolutionary distances were calculated by the Kimura's twoparameter model (Kimura, 1980), without alignment gaps, and unidentified base positions were taken into account during distance calculations. The phylogenetic tree was constructed using the neighbor-joining method (Saitou and Nei, 1987), and the bootstrap values were calculated on the basis of 1,000 replications (Felsenstein, 1985).

Two different DNA-DNA hybridization (DDH) tests were performed. First, DDH was assessed by means of colorimetric microdilution plate hybridization using a kit that is commercially available in Japan (DDHLegionel/a; Kyokuto Pharmaceuticals, Tokyo, Japan). The DDH-Legionella kit identifies sample strains by analysis of the hybridization between the sample DNA and the immobilized DNA of 25 standard strains (L.jordanis, L.pneumophila, L. bozamanii, L. micdadei, L. gormanii, L. longbeachae, L. dumoffii, L. oakridgensis, L. wadworthii, L. feeleii, L. sainthelensi, L. hackeliae, L. jamestowniensis, L.cherrii, L. rubrilucens, L. maceachernii, L. anisa, L. spiritensis, L. israelensis, L.parisiensis, L. santicrucis, L. steigerwaltii, L. erythra, L. birminghamensis, L. cincinnatiensis).

Second, another quantitative microplate DDH test on the HYMO-6 strain and L. oakridgensis KFYY-2 (=JCM 17230) which had the closest relationship in the phylogenetic tree based on the 16S rDNA of the genus Legionella was carried out at the Techno Suruga Laboratory in Shizuoka Prefecture, Japan, as described previously (Kawamura, 2000). The methods used to isolate and purify DNA have been described previously (Hamamoto, 1994). The levels of DNA relatedness were determined using the immobilized microplate method performed at $41^{\circ} \mathrm{C}$. A fluorescence plate reader (Genios, Tecan Japan Co. Ltd., Kanagawa, Japan) was used to measure the intensity of fluorescence. Examinations were performed in triplicate, and the mean values were calculated.

The Gram reaction was determined by using the Nissui Gram stain kit (Tokyo, Japan) according to the manufacturer's instructions. The shape and motility of bacterial cells were observed under a phasecontrast microscope $(\times 1,000)$ with cell suspensions made from cultures grown on BCYE $\alpha$ agar (Merck Ltd. • Japan, Tokyo) at $36^{\circ} \mathrm{C}$ for $3 \mathrm{~d}$. Scanning electron microscope observations were performed on samples fixed to glass filters at the Osaka Prefectural Institute of Public Health, Japan. The samples were fixed with $2 \%$ glutaraldehyde- $2 \%$ paraformaldehyde in $0.1 \mathrm{M}$ phosphate buffer $(\mathrm{pH} 7.2)$, critical-point dried, sputter-coated with osmium, and visualized by using a scanning electron microscope (JSM-T100, JEOL Ltd., Tokyo, Japan). The cultures were plated on BCYE $\alpha$ agar and on Mueller-Hinton agar (Becton, Dickinson and Company, USA) with and without the addition of $5 \%$ sheep blood at $36{ }^{\circ} \mathrm{C}$ for $7 \mathrm{~d}$. Biochemical tests for gelatinase, urease, and catalase, as well as for hippurate hydrolysis and nitrate reduction, were performed as described previously (Kuroki et al., 2007). The oxidase and $\beta$ lactamase activities were examined by a test paper containing tetramethyl-phenylenediamine dihydrochloride (Nissui Pharmaceutical Co. Ltd., Tokyo, Japan) and nitrocefin discs (Becton, Dickinson and Co., Sparks, MD), respectively.

The API ZYM system (SYSMEX bioMérieux Co., Ltd., Tokyo) was used to test the legionellae cultures for 19 different enzymatic activities. The recommendations of the manufacturers were followed for preparing the cell suspensions and for conducting, incubating, and reading the tests. Cell suspensions were made from cultures that were grown on BCYE $\alpha$ agar at $36^{\circ} \mathrm{C}$ for $5 \mathrm{~d}$.

Antibiotic susceptibility was determined using the Etest (SYSMEX bioMérieux Co., Ltd., Tokyo) according to the manufacturer's technical guidelines. The drugs tested were erythromycin (EM), clarithromycin (CAM), azithromycin (AZM), minocycline (MINO), levofloxacin (LVFX), ciprofloxacin (CPFX), piperacillin (PIPC), imipenem (IPM), gentamicin (GM) and rifampicin (RFP) (total 10 drugs). A bacterial cell suspension $(0.5 \mathrm{ml})$ was dripped onto $60 \mathrm{ml}$ of BCYE $\alpha$ agar in a 150-mm dish (Corning Inc., USA) and smeared over the surface using a Conradi stick, and the Etest strips were securely attached to 
the medium. The plates were cultured at $36^{\circ} \mathrm{C}$ for $5 \mathrm{~d}$, and the growth inhibition zone that formed around the strip was read. The MIC was judged by macroscopically reading the graduation at which the end of the growth inhibition zone and the strip crossed.

The analysis of the cellular fatty acid composition was performed using a Sherlock Microbial Identification System (Version 4.5) (MIDI, Newark, DE, USA) at the Techno Suruga Laboratory (Shizuoka, Japan). The cellular fatty acid profile was compared with the known profiles of other strains (Diogo et al., 1999). The guanine-plus-cytosine $(\mathrm{G}+\mathrm{C})$ content of DNA from the isolate was determined using the method described by Tamaoka and Komagata (1984) at the Japan Food Research Laboratories (Tokyo, Japan). Genomic DNA was extracted from cultured cells by the phenol extraction method, and nucleosides were obtained from DNA by the hydrolysis of phosphatase. The various peaks of nucleosides were isolated and detected by HPLC, and the $\mathrm{G}+\mathrm{C}$ content was calculated.

To investigate the pathogenicity of strain HYMO-6, isolates were tested for intra-amoebic growth according to the amoeba-agar method developed by Miyamoto et al. (2003), as follows: The surface of the BCYE $\alpha$ agar (Merck Ltd. Japan, Tokyo, Japan) was sufficiently dried, and $3 \mathrm{ml}$ of a suspension of the Acanthamoeba JAC/E1 strain that had been cultured in PYGC medium ( $10 \mathrm{~g}$ proteose peptone, $10 \mathrm{~g}$ yeast extract, $10 \mathrm{~g}$ glucose, $5 \mathrm{~g} \mathrm{NaCl}, 0.95 \mathrm{~g}$ L-cysteine- $\mathrm{HCl}$, $1.74 \mathrm{~g} \mathrm{~K}_{2} \mathrm{HPO}_{4}, 1.36 \mathrm{~g} \mathrm{KH}_{2} \mathrm{PO}_{4}$, DW $1,000 \mathrm{ml}$ ) at $30^{\circ} \mathrm{C}$ for $7 \mathrm{~d}$ was dropped onto and spread over the entire surface. The agar plate was incubated at $30^{\circ} \mathrm{C}$ for $3 \mathrm{~h}$ to allow the amoebas to firmly adhere, and then the excess suspension was removed. Samples were applied simultaneously to this medium (referred to below as amoeba-agar) and BCYE $\alpha$ medium, and were cultured at $30^{\circ} \mathrm{C}$ for $7 \mathrm{~d}$. Samples that formed colonies in both culture media were regarded as being able to grow in the presence amoebas. The clinical

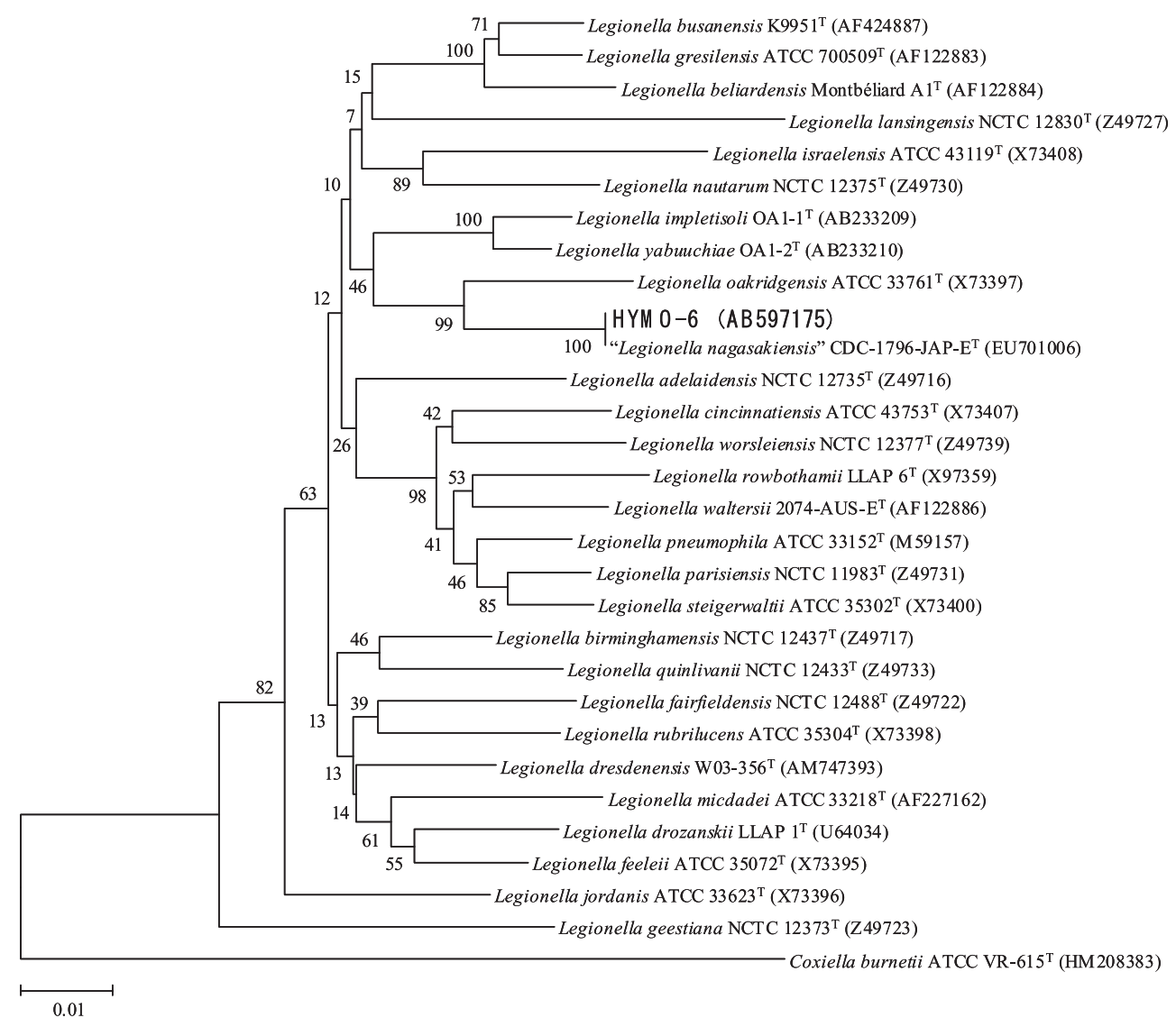

FIG. 1. A phylogenetic tree constructed using the neighbor-joining method based on the $16 \mathrm{~S}$ rRNA partial region sequences $(1,496 \mathrm{bp})$ of strain HYMO-6 (accession number: AB597175) and related bacteria. Coxiella burnetii ATCC VR-615 ${ }^{\top}$ (HM208383) served as an outgroup. The data set was resampled 1,000 times by using the bootstrap option, and the percentage values are given at the nodes. The scale bar indicates the number of substitutions per nucleotide position. 
isolate L. pneumophila IID 5232 and attenuated strain L. pneumophila 25 D (Horwitz, 1987) were used as positive and negative controls, respectively.

The almost complete 16S rDNA gene sequence $(1,496 \mathrm{bp})$ of strain HYMO-6 was determined (accession number: AB597175), and the values of the 16S rDNA gene sequence similarity between strain HYMO-6 and the closest relatives were 96.6\% ( $L$. oakridgensis ATCC 33761 ${ }^{\top}$ ) (Orrison et al., 1983),

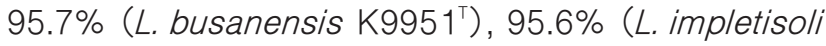
$\mathrm{OA} 1-1^{\top}$ and L. birminghamiensis NCTC $12437^{\top}$ ), and 95.5\% (L. yabuuchiae OA $1-2^{\top}$ ).

By evaluating the DNA-DNA hybridization, $L$. pneumophila IID 5232 strain was identified by $L$. pneumophila, and L.oakridgensis KFYY-2 (JCM 17230) strain was identified by L. oakridgensis. However, the HYMO-6 strain did not correspond to any of the previously identified Legionella species.

The DNA-DNA hybridization similarity values were obtained under optimal conditions, namely, at $41^{\circ} \mathrm{C}$. The HYMO-6 isolate showed less than $16.0 \%$ similarity to the strain of L. oakridgensis which had the closest relationship in the phylogenetic tree based on the $16 \mathrm{~S}$ rDNA of the genus Legionella. It was thought that these results clearly demonstrated that the HYMO-6 strain should be categorized as a new taxon (Wayne et al., 1987). However, in FIG.1, a neighbor-joining tree showed that strain HYMO-6 (=JCM 17450 $=\mathrm{KCTC} 23560=\mathrm{DSM}$ 24727) was same as Legionella nagasakiensis CDC-1796-JAP-E ${ }^{\top}$ (=ATCC BAA $-1557^{\top}=J C M 15315^{\top}$ ) a novel species of the genus Legionella that was reported earlier this year (Yang et al., 2011).

In TABLE 1, we list the important phenotypic characteristics of strain HYMO-6 and compare them with those of the most closely related strains, $L$. oakridgensis, and L. pneumophila. The cells of strain HYMO-6 were Gram-negative, motile, non-sporeforming rods. A photomicrograph of strain HYMO-6 cultured on BCYE $\alpha$ agar at $36^{\circ} \mathrm{C}$ for $7 \mathrm{~d}$ is shown in FIG. 2. The size of these cells was comparatively small at 0.3-0.4 $\times 1.2-2.2 \mu \mathrm{m}$, but longer cells were not observed. The colonies of strain HYMO-6 were gray-pigmented, with a diameter of about $1.0 \mathrm{~mm}$ on BCYE $\alpha$ agar after $7 \mathrm{~d}$ of incubation at $36^{\circ} \mathrm{C}$. Colonies of strain HYMO-6 on sheep blood agar and MuellerHinton agar were not observed at $36^{\circ} \mathrm{C}$ after incubation for $7 \mathrm{~d}$. Strain HYMO-6 was only positive for catalase, and was negative for oxidase and $\beta$-lacta mase activities, whereas $L$. oakridgensis was positive for all three enzymes.

In the 19 API ZYM tests, the HYMO-6 strain was

TABLE 1. Phenotypic characteristics of three Legionella species.

\begin{tabular}{|c|c|c|c|}
\hline Characteristics & $\mathrm{HYMO}=6$ & $\begin{array}{c}\text { L.oakridgensis } \\
\text { KFYY-2 (=JCM 17230) }\end{array}$ & $\begin{array}{l}\text { L.pneumophila } \\
\text { IID } 5232\end{array}$ \\
\hline Gram staining & - & - & - \\
\hline Spore & - & - & - \\
\hline Cell shape & $\mathrm{R}$ & $\mathrm{R}$ & $\mathrm{R}$ \\
\hline Size $(\mu \mathrm{m})$ & $0.3-0.4 \times 1.2-2.2$ & $0.3-0.5 \times 2-11$ & $0.3-0.7 \times 2-15$ \\
\hline Motility & + & + & + \\
\hline \multicolumn{4}{|l|}{ Growth on: } \\
\hline BCYE $\alpha$ agar & + & + & + \\
\hline Sheep blood agar & - & - & - \\
\hline Mueller-Hinton agar & - & - & - \\
\hline \multicolumn{4}{|l|}{ Biochemical reaction } \\
\hline Oxidase & - & + & + \\
\hline Catalase & + & + & - \\
\hline Urease & - & - & - \\
\hline Gelatin liquefaction & - & - & + \\
\hline Nitrate reduction & - & - & - \\
\hline$\beta$-Lactamase & - & + & + \\
\hline Hippurate hydrolysis & - & - & + \\
\hline \multicolumn{4}{|c|}{ Enzyme actibity (API ZYM test) } \\
\hline Alkaline phosphatase & + & w & w \\
\hline Acid phosphatase & w & + & + \\
\hline Leucine aminopeptidase & + & + & w \\
\hline \multicolumn{4}{|l|}{ Susceptibility (MIC, $\mu \mathrm{g} / \mathrm{ml}$ ) } \\
\hline Azithromycin & 2 & 2 & 0.25 \\
\hline Piperacillin & 2 & 0.25 & 4 \\
\hline Gentamicin & 4 & 1 & 2 \\
\hline
\end{tabular}

R: rod, w: weak 


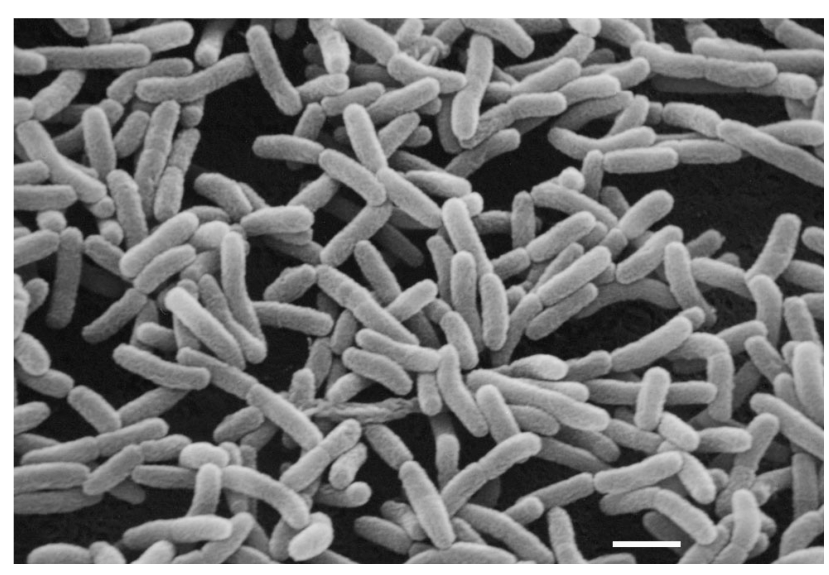

FIG. 2. A photomicrograph of cells of strain HYMO-6 cultured on BCYE $\alpha$ agar at $36^{\circ} \mathrm{C}$ for $7 \mathrm{~d}$. The scale bar indicates $1 \mu \mathrm{m}$.

characterized as having strong alkaline phosphatase and leucine arylamidase activity, moderately strong C4 and C8 esterase activity, weak acid phosphatase activity, and to lack both proteolytic (trypsin and chymotrypsin) and carbohydrate-degrading enzyme activities (TABLE 1).

Strain HYMO-6 was susceptible to $\mathrm{EM} \quad(\mathrm{MIC}=1$ $\mu \mathrm{g} / \mathrm{ml}), \mathrm{CAM}(\mathrm{MIC}=0.5 \mu \mathrm{g} / \mathrm{ml}), \mathrm{AZM}(\mathrm{MIC}=2 \mu \mathrm{g} /$ $\mathrm{ml}), \operatorname{MINO}(\mathrm{MIC}=4 \mu \mathrm{g} / \mathrm{ml}), \operatorname{LVFX}(\mathrm{MIC}=0.5 \mu \mathrm{g} / \mathrm{ml})$, CPFX $(\mathrm{MIC}=1 \mu \mathrm{g} / \mathrm{ml})$, PIPC $(\mathrm{MIC}=2 \mu \mathrm{g} / \mathrm{ml}), \mathrm{IPM}$ $(\mathrm{MIC}=0.016 \mu \mathrm{g} / \mathrm{ml}), \mathrm{GM}(\mathrm{MIC}=4 \mu \mathrm{g} / \mathrm{ml})$, and $\mathrm{RF}$ $(\mathrm{MIC}=0.016 \mu \mathrm{g} / \mathrm{ml})$. As shown in TABLE 1, the susceptibility of strain HYMO-6 resembled that of other legionellae.

Strain HYMO-6 contained unsaturated fatty acids, predominantly $16: 1 \omega 7 \mathrm{c}$ (32.4\%), followed by $16: 0$ (24.8\%) and $18: 0(13.4 \%)$ fatty acids. The other fatty acids detected were: cyc17:0 (5.6\%); i16:0 (4.7\%); 20:0 (3.7\%); a 17:0 (3.0\%) and 17:0 (2.9\%). The fatty acid composition also demonstrated that this strain did not correspond to any previously described Legionella species (Diogo et al., 1999). The fatty acid composition of strain HYMO-6 most closely resembled that of $L$. oakridgensis in the high ratio of 18:0, but strain HYMO-6 differed from L. oakridgensis in that it had a low ratio of i16:0. According to Park et al. (2003), L. busanensis contains predominantly 16 : $1 \omega 7 \mathrm{c}$, but the present strain had a high $16: 1 \omega 7 \mathrm{c}$ content of $43 \%$. The fatty acid profiles further supported that strain HYMO-6 was different from other previously characterized Legionella species. The DNA $\mathrm{G}+\mathrm{C}$ content of strain HYMO-6 was 42.0 mol\%, which was similar to the $42.5 \mathrm{~mol} \%$ of $L$. dresdenensis (Luck et al., 2010) and the 42.6 mol\% of L. lansingensis (Thacker et al, 1992).

In this study, strain HYMO-6 formed a colony on amoeba-agar medium, as did the positive control ( $L$. pneumophila IID 5232) (FIG. 3). This colony did not differ at all from that formed on BCYE $\alpha$ agar medium used as a control, suggesting that this strain was able to successfully grow in Acanthamoeba sp. JAC/E1 strain cells. The bacteria of the genus Legionella can grow intracellularly in protists that phagocytize bacteria, meaning they will have the ability to grow in human and animal macrophages. This property of the bacterium is reportedly important in terms of the pathogenicity of the genus Legionella. It is a wellknown fact that the growth of Legionella spp. in cells contributes to the pathogenicity of these bacteria, and since the growth of strain HYMO-6 in Acanthamoeba sp. JAC/E1 strain has been confirmed, this finding thus suggests that strain $\mathrm{HYMO}-6$ would therefore be pathogenic. This was strongly supported by the fact that this strain was isolated from a patient diagnosed with Legionnaires' disease in the U.S. (Yang et al., 2011)

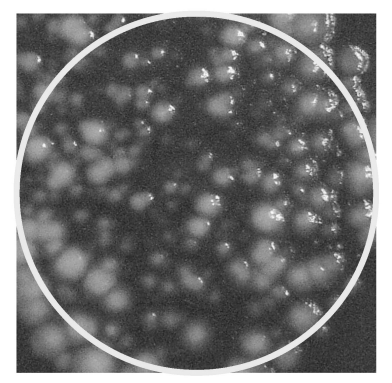

IID5232 (positive control)

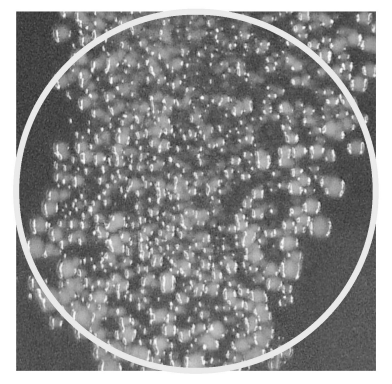

HYMO-6

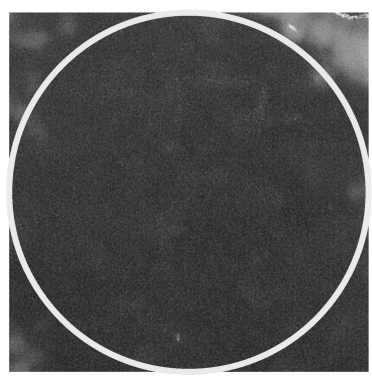

25D (negative control)

FIG. 3. The intracellular growth capacity of strain HYMO-6 evaluated by the amoeba-agar method. 


\section{ACKNOWLEDGEMENTS}

We sincerely thank Mr. Hiroshi Nishimura of the Osaka Prefectural Institute of Public Health who assisted us in performing the electron microscopic photography. This research was partially supported by a research project grant awarded by the Azabu University Research Services Division.

\section{REFERENCES}

Albers, U., Reus, K., Shuman, H.A., and Hilbi, H. (2005) The amoebae plate test implicates a paralogue of $/ p x \mathrm{~B}$ in the interaction of Legionella pneumophila with Acanthamoeba castellanii. Microbiol., 151, 167-182.

Amemura-Maekawa, J., Kura, F., Bin, C., Suzuki-Hashimoto, A., Ichinose, M., Endo, T., and Watanabe, H. (2008) Distinct difference of fla A genotypes of Legionella pneumophila between isolates from bath water and cooling tower water. Microbiol. Immunol., 52, 460-464.

Building Management Education Center (2009) Manual for the countermeasure to legionellosis 3rd. ed., pp.7, Building Management Education Center, Tokyo.

Diogo, A., Verissimo, A., Nobre, M.F., and Costa, da M.S. (1999) Usefulness of fatty acid composition for differentiation of Legionella species. J. Clin. Microbiol., 37, 22482254.

Edelstein, P.H., and Meyer, R.D. (1980) Susceptibility of Legionella pneumophila to twenty antimicrobial agents. Antimicrob. Agents Chemother., 18, 403-408.

Felsenstein, J. (1985) Confidence limits on phylogenies: an approach using the bootstrap. Evolution, 39, 783-791.

Fraser, D.W., Tasai, T.R., Orenstein, W., Parkin, W.E., Beecham, H.J., Sharrar, R.G., Harris, J., Mallison, G.F., Martin, S.M., McDade, J.E., Shepard, C.C., Branchman, P.S., and The Field Investigation Team (1977) Legionnaires' disease, Description of an epidemic of pneumonia. N. Engl. J. Med., 297, 1189-1197.

Furuhata, K., Hara, M., Yoshida, S., and Fukuyama, M. (2004) Distribution of Legionella spp. in hot spring baths in Japan (in Japanese). Kansenshogaku Zasshi, 78, 710716.

Furuhata, K., Ogihara, K., Okuno, R., Oonaka, K., and Fukuyama, M. (2009) Growth in Acanthamoeba sp. and antibiotic susceptibility of Legionella micdadei isolated from hot spring water samples. Biocontrol Sci., 14, 181184.

Furuhata, K., Ogihara, K., Ishizaki, N., Oonaka, K., Yoshida, Y., Goto, K., Hara, M., Miyamoto, H., Yoshida, S., and Fukuyama, M. (2010) Identification of Legionel/a londiniensis isolated from hot spring water samples in Shizuoka, Japan, and cytotoxicity of isolates. J. Infect. Chemother., 16, 367-371.

Hall, T.A. (1999) BioEdit: a user-friendly biological sequence alignment editor and analysis program for Windows 95/98 NT. Nucleic Acids Symp. Ser., 41, 95-98.

Hamamoto, M. (1994) DNA Extraction (in Japanese). Microbiol. Cult. Coll., 10, 116-118.

Horwitz, M.A. (1987) Characterization of a virulent mutant Legionella pneumophila that survive but do not multiply within human monocytes. J. Exp. Med., 166, 1310-1328.

Kawamura, Y. (2000) Quantitative microplate DNA-DNA hybridization test (in Japanese). Jpn. J. Bacteriol., 55, 558-567.

Kimura, M. (1980) A simple method for estimating evolutionary rates of base substitution through comparative studies of nucleotide sequences. J. Mol. Evol., 16, $111-120$

Kuroki, H., Miyamoto, H., Fukuda, K., lihara, H., Kawamura, Y., Ogawa, M., Wang, Y., Ezaki, T., and Taniguchi, H. (2007) Legionella impletisoli sp. nov. and Legionella yabuuchiae sp. nov., isolated from soils contaminated with industrial wastes in Japan. Sys. Appl. Microbiol., 30, 273-279.

Lück, P.C., Jacobs, E., Röske, I., Schöter-Bobsin, U., Dumke, R., and Gronow, S. (2010) Legionella dresdenensis sp. nov., isolated from river water. Int. J. Syst. Evol. Microbiol., 60, 2557-2562.

Miyamoto, H., Taniguchi, H., and Yoshida, S. (2003) A simple qualitative assay for intracellular growth of Legionella pneumophila within Acanthamoeba culbertsoni (in Japanese). Kansensyogaku Zassi, 77, 343-345.

Orrison, L.H., Cherry, W.B., Tyndall, R.L., Fliermans, C.B., Gough, S.B., Lambert, M. A., McDougal, L.K., Bibb, W.F., and Brenner, D.J. (1983) Legionella oakridgensis: unusual new species isolated from cooling tower water. Appl. Environ. Microbiol., 45, 536-545.

Park, M-Y., Ko, K.S., Lee, H.K., Park, M-S., and Kook, Y-H. (2003) Legionella busanensis sp. nov., isolated from cooling tower water in Korea. Int. J. Syst. Evol. Microbiol., 53, 77-80.

Riffard, S., Presti, F.L., Vandenesch, F., Forey, F., Reyrolle, M., and Etienne, J. (1998) Comparative analysis of infrequent-restriction-site PCR and pulsed-field gel electrophoresis for epidemiological typing of Legionella pneumophila serogroup 1 strains. J. Clin. Microbiol., 36, 161-167.

Saitou, N., and Nei, M. (1987) The neighbor-joining method: A new method for reconstructing phylogenetic trees. Mol. Biol. Evol., 4, 406-425.

Tamaoka, J., and Komagata, K. (1984) Determination of DNA base composition by reversed-phase highperformance liquid chromatography. FEMS Microbiol. Lett., 25, 125-128.

Thacker, W.L., Dyke, J.W., Benson, R.F., Havlichek, D.H. Jr., Robinson-Dunn, B., Stiefel, H., Schneider, W., Moss, C.W., Mayberry, W.R., and Brenner, D.J. (1992) Legionella lansingensis sp. nov. isolated from a patient with pneumonia and underlying chronic lymphovytic leukemia. J. Clin. Microbiol., 30, 2398-2401.

Thompson, J.D., Higgins, D.G., and Gibson, T.J. (1994) CLUSTAL W: improving the sensitivity of progressive multiple sequence alignment through sequence weighting, positions-specific gap penalties and weight matrix choice. Nucleic Acids Res., 22, 4673-4680.

Wayne, L.G., Brenner, D.J., Colwell, R.R., Grimont, P.A.D., Kandler, O., Krichevsky, L., Moore, L.H., Moore, W.C., Murray, R.G.E., Stackebrandt, E., Starr, M.P., and Truper, H.G. (1987) Report of the ad hoc committee on reconciliation of approaches to bacteria systematics. Int. J. Syst. Bacteriol., 37, 463-464.

Yabuuchi, E., and Agata, K. (2004) An outbreak of legionellosis in a new facility of hot spring bath in Hiuga city (in Japanese). Kansensyogaku Zassi, 78, 90-98.

Yang, G., Benson, R.F., Ratcliff, R.M., Brown, E.W., Steigerwalt, A.G., Thacker, W.L., Daneshvar, M.I., Morey, R.E., Saito, A., and Fields, B.S. (2011) Legionella nagasakiensis sp. nov., isolated from water samples in Japan and Australia and from a patient with pneumonia in the United States. Int. J. Syst. Evol. Microbiol., in press. 